\title{
MLL/CASC5 Fusion Gene
}

National Cancer Institute

\section{Source}

National Cancer Institute. MLL/CASC5 Fusion Gene. NCI Thesaurus. Code C99349.

A fusion gene that results from a chromosomal translocation $\mathrm{t}(11 ; 15)(\mathrm{q} 23 ; \mathrm{q14})$ which

fuses exon 8 or exon 9 of the MLL gene and exon 10 or exon 12 of the CASC5 gene. This rearrangement may be associated with acute myeloid leukemia and acute lymphoblastic leukemia. 